\title{
$\frac{100}{\mathrm{LuT}} \mathrm{RPES}$
}

\section{BEZPOŚREDNI SKUTEK OGÓLNEJ ZASADY NIEDYSKRYMINACJI W SPORACH DOTYCZĄCYCH DZIEDZIN OBJĘTYCH PRAWEM UNII EUROPEJSKIEJ}

\section{WPROWADZENIE}

Bezpośredni skutek to koncepcja niezwykle ważna dla jednostek, wiąże się z nim bowiem możliwość powołania się przez nie przed krajowymi organami stosowania prawa (sądami lub organami administracyjnymi) na prawa wynikajace z norm unijnych, o ile tylko spełniaja one pewne kryteria ${ }^{1}$. Zostały one określone przez Trybunał w wyroku w sprawie Van Gend en Loos ${ }^{2}$, były jednak następnie łagodzone, co ciekawe, głównie w rozstrzygnięciach odnoszacych się do zasady niedyskryminacji. Zgodnie z orzecznictwem bezpośredni skutek norm unijnych nie jest koncepcją jednorodna, ale może występować w układzie: wertykalnym (pionowym) oraz horyzontalnym (poziomym). Z tym pierwszym spotykamy się wówczas, gdy jednostki mogą powoływać się na normę unijną przeciwko państwu członkowskiemu, a z tym drugim, gdy czynią to $\mathrm{w}$ sporach prawa prywatnego, a więc przeciwko innym jednostkom. Zwłaszcza to drugie zagadnienie jest niezmiernie istotne $\mathrm{w}$ kontekście zasady niedyskryminacji, która może być przecież naruszana nie tylko przez państwa i ich organy, ale również przez osoby fizyczny i prawne. W literaturze przedmiotu podkreśla się przy tym, że „stosowanie tej zasady w sporach prywatnych jest delikatną kwestia, ponieważ rodzi zasadnicze pytania dotyczące podziału kompetencji między Unią a państwami członkowskimi, wewnętrznego podziału kompetencji między Trybunałem Sprawiedliwości a prawodawcą UE

\footnotetext{
Justyna Maliszewska-Nienartowicz, Uniwersytet Mikołaja Kopernika w Toruniu, mal-nie@econ.umk.pl, https://orcid.org/0000-0001-8266-3104

1 Mik (2000): 241-242.

2 Wyrok TS z 5 lutego1963 r., sprawa 26/62, NV Algemene Transport-en Expeditie Onderneming van Gend \& Loos v Netherlands Inland Revenue Administration, ECLI:EU:C:1963:1.
} 
(równowaga instytucjonalna) i podziału na sektor publiczny i prywatny (the public-private divide") $)^{3}$.

W rezultacie można postawić pytanie, dlaczego mimo tych zastrzeżeń w orzecznictwie TS dostrzegalna jest wyraźna tendencja do rozszerzenia zakresu skuteczności zasady niedyskryminacji. Należy przyjać hipotezę, że tak jak głównym celem wprowadzenia koncepcji bezpośredniego skutku do wspólnotowego (obecnie unijnego) porządku prawnego była chęć ochrony praw jednostek, tak i w tym przypadku chodzi przede wszystkim o ochronę ofiar dyskryminacji, a drugorzędne znaczenie ma eliminacja sytuacji, w której podmioty dyskryminujące unikają odpowiedzialności z tego tytułu. Warto także rozważyć, jakie mogą być skutki przyjętej w orzecznictwie koncepcji, że tytułowa zasada wywołuje zarówno bezpośrednie skutki wertykalne, jak i horyzontalne. W tym zakresie trzeba założyć, że skutkiem takiego podejścia Trybunału jest nałożenie na podmioty prywatne dodatkowych zobowiąań w zakresie przestrzegania unijnej zasady niedyskryminacji, także wówczas gdy krajowe regulacje prawne sa z nią sprzeczne. Tak naprawdę zatem mamy do czynienia z sytuacja, w której na jednostki zostaje przeniesiona część ciężaru związanego z ochrona praw podstawowych, która spoczywała dotychczas na państwach członkowskich - w przypadku naruszenia zasady oba podmioty sa zobowiązane do wyeliminowania jego niekorzystnych skutków ${ }^{4}$.

\section{ROZWÓJ ORZECZNICTWA DOTYCZĄCEGO BEZPOŚREDNIEGO SKUTKU ZAKAZÓW DYSKRYMINACJI/ ZASADY NIEDYSKRYMINACJI}

Początkowo traktaty założycielskie Wspólnot zawierały ogólne zakazy dyskryminacji odnoszące się do dwóch kryteriów: przynależności państwowej (art. 7 TEWG, obecnie art. 18 TFUE) oraz płci (zasada równości wynagrodzeń - art. 119 TEWG, obecnie art. 157 TFUE). Trybunał dość wcześnie odniósł się do zagadnienia bezpośredniego skutku art. 119 TEWG - nastapiło to już w wyroku w sprawie Defrenne ${ }^{5}$, mimo że występujące w tej regulacji pojęcia, jak choćby „wynagrodzenie” czy „taka sama” praca, nie były dostatecznie precyzyjne. Rozstrzygnięcie to było istotne także z tego względu, że Trybunał, powołujac się na wiążacy charakter omawianego postanowienia, doszedł do wniosku, że ustanowiony w nim zakaz dyskryminacji ze względu na płeć „obowiązuje nie tylko wobec władz publicznych, lecz dotyczy także wszelkich układów regulujących w sposób zbiorowy pracę najemna, a także umów między osobami fizycznymi czy prawnymi”6. Tym samym uznał, że może on wywołać bezpośredni skutek horyzontalny. Takie samo podejście

\footnotetext{
${ }^{3}$ De Mol (2011): 110.

${ }^{4}$ Fontanelli (2011): 238-239.

${ }^{5}$ Wyrok TS z 8 kwietnia 1976 r., sprawa 43/75, Gabrielle Defrenne v Société anonyme belge de navigation aérienne Sabena, ECLI:EU:C:1976:56.

${ }^{6}$ Ibid.: pkt 39.
} 
zostało przyjęte w wyroku w sprawie Anognese ${ }^{7}$ w stosunku do zakazu dyskryminacji opartego na przynależności państwowej. Trybunał Sprawiedliwości podkreślił bowiem, że ustanowiona w art. 48 Traktatu ustanawiającego Wspólnotę Europejską (TWE, obecnie art. 45 TFUE) zasada niedyskryminacji została sformułowana w sposób ogólny i nie jest adresowana szczególnie do państw członkowskich, można się zatem na nią powoływać także w sporach między podmiotami prywatnymi ${ }^{8}$. W rezultacie $\mathrm{w}$ zakresie ich odpowiedniego zastosowania (głównie w sferze zatrudnienia) art. 157 i 45 ust. 2 TFUE znajdują pełne bezpośrednie zastosowanie w relacjach między jednostkami (osobami fizycznymi i prawnymi) ${ }^{9}$.

Zbliżone podejście przyją TS w wyroku w sprawie Mangold ${ }^{10}$, w którym odniósł się do ogólnej zasady niedyskryminacji ze względu na wiek. Wskazał tam, że sąd krajowy jest odpowiedzialny za zagwarantowanie pełnej skuteczności tej zasady również $\mathrm{w}$ sporach $\mathrm{z}$ udziałem podmiotów prywatnych „poprzez niestosowanie wszelkich przepisów prawa krajowego, które są z nią sprzeczne również wtedy, gdy termin na dokonanie transpozycji tej dyrektywy jeszcze nie upłynął"11. Chociaż niektórzy przedstawiciele doktryny zaakceptowali ustanowienie ogólnej zasady niedyskryminacji ze względu na wiek ${ }^{12}$, stanowisko to spotkało się również z krytyką. W szczególności kilku rzeczników generalnych skomentowało rozstrzygnięcie w sprawie Mangold, sugerując bardziej ograniczoną interpretację, zgodnie z którą zakaz dyskryminacji ze względu na wiek określony przez Trybunał stanowi jedynie szczególny wyraz ogólnej zasady równości ${ }^{13}$. W doktrynie podkreślono również, że nierozsądne byłoby przyjęcie twierdzenia, że ogólna zasada równości wywołuje bezpośrednie skutki horyzontalne we wszystkich sytuacjach wchodzących w zakres prawa wspólnotowego (obecnie unijnego) ${ }^{14}$. Jednakże „nie należy wykluczać, że ogólna zasada prawa wspólnotowego może, w odpowiednich okolicznościach, być stosowana horyzontalnie" ${ }^{15}$. W rezultacie głównym zadaniem Trybunału na przyszłość było określenie zakresu bezpośredniej skuteczności zasady niedyskryminacji w sporach prywatnego, ponieważ nie było do końca jasne, czy taki skutek wywołuje jedynie zasada niedyskryminacji ze względu na wiek

${ }^{7}$ Wyrok TS z 6 czerwca 2000 r., C-281/98, Roman Angonese v. Cassa di Risparmio di Bolzano SpA., ECLI:EU:C:2000:296.

8 Ibid.: pkt 30 i 36.

9 De Mol (2011): 115.

${ }^{10}$ Wyrok TS z 22 listopada 2005 r., C-144/04, Werner Mangold v. Rüdiger Helm, ECLI: EU:C:2005:709.

${ }^{11}$ Ibid.: pkt 78.

${ }^{12}$ Schiek (2010): 370-371. Autorka ta zauważa również, że od czasu wejścia w życie Traktatu z Lizbony zasada niedyskryminacji ze względu na wiek stanowi niezaprzeczalnie część prawa UE jako zasada ogólna.

${ }_{13}$ Tak. m.in. rzecznik generalny Sharpston w opinii w sprawie C-227/04 P, Maria-Luise Lindorfer $v$. Council of the European Union, ECLI:EU:C:2006:748, pkt 52-58, czy rzecznik generalny Mazák w opinii w sprawie C-411/05, Félix Palacios de la Villa v. Cortefiel Servicios SA., ECLI:EU:C:2007:106: pkt 87-97 oraz 132-138.

${ }^{14}$ Wyatt (2008): 15.

${ }_{15}$ Tak rzecznik generalny Sharpston w opinii w sprawie C-427/06, Birgit Bartsch v. Bosch und Siemens Hausgeräte (BSH) Altersfürsorge GmbH, ECLI:EU:C:2008:297: pkt 85. 
czy też również oparta na innych przyczynach, takich jak religia lub przekonania, niepełnosprawność, orientacja seksualna oraz pochodzenie rasowe lub etniczne.

Wszystkie te problemy nie zostały rozwiązane w sprawie Kücükdeveci ${ }^{16}$, chociaż TS starał się wyjaśnić swoje wcześniejsze podejście. Odniósł się do art. 21 ust. 1 Karty praw podstawowych UE (Karta) ${ }^{17}$ jako potencjalnego źródła zasady niedyskryminacji ze względu na wiek, ale jednocześnie podkreślił, że zasada ta została wyrażona również w dyrektywie 2000/78/WE ${ }^{18}$. Warto zauważyć, że to wskazanie na KPP w wyroku Kücükdeveci zapoczątkowało debatę na temat bezpośredniego horyzontalnego zastosowania tego dokumentu albo niezależnie, albo też jako wyrazu ogólnych zasad prawa Unii ${ }^{19}$. Natomiast w odniesieniu do zakresu zasady niedyskryminacji ze względu na wiek Trybunał zauważył jedynie, że należy ją stosować w ramach prawa Unii Europejskiej. Nie wyjaśnił przy tym, dlaczego ma ona wywoływać bezpośrednie skutki horyzontalne - TS podkreślił tylko, że sądy krajowe powinny zapewnić jej pełną skuteczność. Dlatego niektórzy przedstawiciele doktryny zauważaja, że rozszerzenie ogólnej zasady niedyskryminacji na sferę prywatna nie ma wystarczającego uzasadnienia i należy je postrzegać jako nadmierne rozbudowanie zakresu prawa UE przez Trybunał ${ }^{20}$.

Podobne stanowisko zajął duński Sąd Najwyższy, który odmówił zastosowania wyroku TS wydanego w sprawie Dansk Industri ${ }^{21}$. Wskazywana przez niego główną przyczyną odmowy było to, że zasada przyznania nie pozwala Trybunałowi na zastosowanie zasady niedyskryminacji do sporów między podmiotami prywatnymi ${ }^{22}$. Nie może to jednak wpłynąć na ważność tego wyroku, który potwierdził horyzontalny bezpośredni skutek zasady niedyskryminacji ze względu na wiek. Po pierwsze, Trybunał zauważył, że źródło tej zasady można znaleźć w różnych instrumentach międzynarodowych i tradycjach konstytucyjnych wspólnych dla państw członkowskich, w tym w art. 21 KPP. Po drugie, TS wyjaśnił, że „zakres ochrony przyznanej tą dyrektywa [2000/78/WE - dop. J.M.-N.] siłą rzeczy nie może być szerszy niż zakres ochrony wynikajaccy z tej zasady"23. W rezultacie zasada niedyskryminacji może być stosowana, jeżeli sytuacja objęta jest zakazem dyskryminacji uregulowanym

16 Wyrok TS z 19 stycznia 2010 r., C-555/07, Seda Kücükdeveci v. Swedex GmbH \& Co. KG., ECLI:EU:C:2010:21.

17 Przepis ten przewiduje, że: „1. Zakazana jest wszelka dyskryminacja w szczególności ze względu na płeć, rasę, kolor skóry, pochodzenie etniczne lub społeczne, cechy genetyczne, język, religię lub przekonania, poglądy polityczne lub wszelkie inne poglądy, przynależność do mniejszości narodowej, majątek, urodzenie, niepełnosprawność, wiek lub orientację seksualną. 2. W zakresie zastosowania Traktatów i bez uszczerbku dla ich postanowień szczególnych zakazana jest wszelka dyskryminacja ze względu na przynależność państwowa”.

18 Dyrektywa 2000/78/WE Rady z 27 listopada 2000 r. ustanawiająca ogólne warunki ramowe równego traktowania w zakresie zatrudnienia i pracy, Dz. Urz. WE L 303: 16.

19 Leczykiewcz (2015): 242.

20 De Mol (2011): 134.

${ }^{21}$ Wyrok TS z 19 kwietnia 2016 r., C-441/14, Dansk Industri (DI), acting on behalf of Ajos A/S v. Estate of Karsten Eigil Rasmussen, ECLI:EU:C:2016:278.

22 Zaccaroni (2010): 14.

${ }^{23}$ Wyrok w sprawie C-441/14: pkt 23. 
w dyrektywie 2000/78/WE ${ }^{24}$. Po trzecie, opierając się na swoim wcześniejszym orzecznictwie $^{25}$, Trybunał podkreślił fundamentalny charakter zasady niedyskryminacji ustanawiającej dla jednostek „prawo podmiotowe, które może być powoływane jako takie, a które - nawet w sporach pomiędzy jednostkami nakazuje sądom krajowym odstapić od stosowania przepisów prawa krajowego, które naruszają tę zasadę"26.

Podejście wskazujące na to, że zasada niedyskryminacji zajmuje szczególne miejsce wśród zasad ogólnych prawa UE zostało utrzymane w późniejszym orzecznictwie dotyczącym innych cech chronionych, w szczególności religii. Wyroki w sprawach Egenberger ${ }^{27}$ oraz IR $v J^{28}$ potwierdziły i umocniły bezpośredni skutek horyzontalny zasady niedyskryminacji w obszarze zatrudnienia, a zarazem dobrze wpisywały się w spójną linię orzeczniczą zapoczątkowaną w wyroku w sprawie Defrenne, a kontynuowana w takich sprawach, jak Mangold, Kücükdeveci czy Dansk Industri ${ }^{29}$. Jednak rozstrzygnięcia te wprowadziły również nowe ważne elementy w odniesieniu do bezpośredniego horyzontalnego skutku zasady niedyskryminacji. Przede wszystkim TS odniósł się w nich do ogólnej zasady niedyskryminacji ze względu na religię lub przekonania, potwierdzając w ten sposób, że doktryna bezpośredniego skutku horyzontalnego obejmuje nie tylko płeć, narodowość czy wiek, lecz także religię. Trybunał rozwiał zatem wątpliwości wyrażone w literaturze przedmiotu co do tego, czy skutek ten dotyczył jedynie dyskryminacji ze względu na wiek, czy również innych przyczyn wymienionych $\mathrm{w}$ Traktatach ${ }^{30}$. Ponadto podkreślono, że zakaz dyskryminacji ze względu na religię lub przekonania „przyznaje jednostkom prawo, na które mogą się one bezpośrednio powoływać w sporze dotyczacym jednej z dziedzin objętych prawem Unii”, oraz że „z uwagi na swój bezwzględnie wiążacy charakter art. 21 Karty co do zasady nie różni się od poszczególnych postanowień traktatów założycielskich zakazujących dyskryminacji z różnych względów, nawet jeżeli owe przypadki dyskryminacji wynikają z umów zawieranych przez jednostki”" ${ }^{31}$. Trybunał zwrócił zatem uwagę na wiążący charakter zasady niedyskryminacji, która jest nie tylko niepisaną zasadą ogólna, ale również została potwierdzona przez państwa członkowskie w Karcie. W związku z tym sąd krajowy jest zobowiązany do zagwarantowania jej pełnej skuteczności przez niestosowanie, jeżeli zajdzie taka potrzeba, sprzecznych z nią przepisów prawa krajowego. Warto jednak zauważyć, że zgodnie z rozstrzygnięciami zarówno w sprawie Egenberger, jak i IR $v J Q$

${ }^{24}$ Zaccaroni (2010): 11.

${ }^{25}$ Chodziło zwłaszcza o wyrok TS z 15 stycznia 2014 r., C-176/12, Association de médiation sociale v. Union locale des syndicats CGT and Others, ECLI:EU:C:2014:2: pkt 47.

${ }^{26}$ Wyrok w sprawie C-441/14: pkt 36.

${ }_{27}$ Wyrok TS z 17 kwietnia 2018 r., C-414/16, Vera Egenberger v. Evangelisches Werk für Diakonie und Entwicklung e.V., ECLI:EU:C:2018:257.

28 Wyrok TS z 11 września 2018 r., C-68/17, IR v. JQ, ECLI:EU:C:2018:696.

29 Ciacchi (2019): 305.

${ }^{30}$ Warto jednak zauważyć, że większość autorów wyrażała przekonanie, iż „przez analogię, to samo podejście zostałoby prawdopodobnie zastosowane również wobec innych zakazów dyskryminacji opartych na podstawach uregulowanych w dyrektywie 2000/78”. Zob. np. De Mol (2011): 24.

31 Wyrok w sprawie C-414/16: pkt 76-77. 
horyzontalny bezpośredni skutek zasady niedyskryminacji pojawia się w sytuacjach, w których nie można interpretować ustawodawstwa krajowego zgodnie z prawem Unii. W pewnym zatem sensie TS traktuje ten skutek jako środek „ostatniej szansy” dla jednostki, kiedy zawiodą inne sposoby zapewnienia ochrony jej praw wynikajacych z tej zasady.

Warto zatem zauważyć, że o ile postanowienia traktatów założycielskich zakazują dyskryminacji ze względu na konkretne kryteria (chodzi zwłaszcza o art. 18 i 157 TFUE, gdyż art. 19 ust.1 TFUE zawiera normę kompetencyjna, upoważniającą instytucje unijne do przyjmowania środków służących zwalczaniu dyskryminacji), o tyle art. 21 ust. 1 Karty ma charakter ogólny, gdyż odwołuje się do wielu różnych podstaw. To właśnie z tego względu jest on często przywoływany łącznie z odpowiednimi postanowieniami dyrektywy 2000/78/WE dla wzmocnienia/ uzupełnienia ich skutków prawnych. Jednocześnie TS podkreśla, że ogólna zasada niedyskryminacji może być stosowana, jeżeli sytuacja objęta jest zakazem dyskryminacji uregulowanym w tym akcie prawa wtórnego lub innych aktach dotyczących dziedzin objętych prawem UE. W takiej sytuacji jednostka może się na nią powoływać nie tylko przeciwko państwu i jego organom, ale także osobom prawnym i fizycznym, co potwierdził Trybunał w kolejnym wyroku.

\section{ROZSTRZYGNIECCIE W SPRAWIE CRESCO INVESTIGATION GMBH ${ }^{32}$ POTWIERDZENIE BEZPOŚREDNIEGO SKUTKU ZASADY NIEDYSKRYMINACJI W SPORACH PRYWATNYCH}

W sprawie tej sąd krajowy dążył do ustalenia, czy mamy do czynienia z dyskryminacją ze względu na religię w przypadku postanowienia przewidującego, że Wielki Piątek jest dniem wolnym od pracy tylko dla pracowników będących członkami niektórych Kościołów chrześcijańskich oraz że jedynie ci pracownicy mają prawo - jeżeli są zobowiązani pracować w ten dzień wolny od pracy do dodatku do wynagrodzenia pobieranego za pracę świadczoną w ten dzień. Trybunał nie miał żadnych wątpliwości, że przedmiotowe regulacje wprowadzają dyskryminację ze względu na religię. Odrzucił także możliwość ich uzasadnienia w świetle art. 2 ust. 5 ('́rodki konieczne w demokratycznym społeczeństwie) oraz art. 7 ust. 1 (działania pozytywne) dyrektywy 2000/78/WE. Pozostała zatem odpowiedź na ostatnie z pytań zadanych przez sąd odsyłający, tzn. czy prywatny pracodawca dopóty, dopóki ustawodawca nie stworzy sytuacji prawnej wolnej od dyskryminacji, powinien zapewnić wszystkim pracownikom, niezależnie od wyznawanej przez nich religii, roszczenia w odniesieniu do Wielkiego Piątku.

${ }^{32}$ Wyrok TS z 22 stycznia 2019 r., C-193/17, Cresco Investigation GmbH v Markus Achatzi, ECLI:EU:C:2019:43. 
Warto zauważyć, że rzecznik generalny Bobek, który wydał opinię w tej sprawie $^{33}$, zajął dość zachowawcze stanowisko, jeśli chodzi o bezpośredni skutek horyzontalny art. 21 Karty i zawartej w nim zasady niedyskryminacji. Odnosząc się do dotychczasowego orzecznictwa TS, wskazał bowiem, że: „wyrok w sprawie Egenberger potwierdza pierwszeństwo prawa pierwotnego Unii w postaci art. 21 ust. 1 Karty w szczególnym kontekście sporu horyzontalnego, w przypadku gdy aktem prawa wtórnego jest dyrektywa, a wykładnia zgodna nie jest możliwa”, oraz że „w wyroku tym (ani w żadnym innym wyroku spośród przytoczonych w poprzednim punkcie) nie ma niczego, co potwierdzałoby, że art. 21 ust. 1 Karty jest »bezpośrednio skuteczny horyzontalnie» w tym sensie, że zasadniczo może sam w sobie stanowić odrębne źródło praw generujących korelujący z nimi obowiazek innego podmiotu w ramach sporu na gruncie prawa prywatnego" ${ }^{34}$. Rozwiązanie, jakie zaproponował, miało być zatem bezpieczne i sprowadzało się do przyznania jednostce prawa do odszkodowania przeciwko państwu w celu naprawienia naruszenia, w końcu to ono było jego sprawcą. Warto jednak zauważyć, że w toku swoich dość długich rozważań na temat środka prawnego, jaki można przyznać jednostce w takim przypadku, jaki był przedmiotem głównego postępowania, rzecznik postawił ważne pytanie odnoszące się do tego, dlaczego pracodawcy maja ponosić koszty stosowania nieprawidłowego ustawodawstwa krajowego ${ }^{35}$. Wskazał także na kwestię spójności orzecznictwa dotyczącego bezpośredniego skutku horyzontalnego - wszak w kontekście sporu między osobami prywatnymi, w sytuacji gdy wykładnia przepisów krajowych w sposób zgodny z dyrektywą nie znajduje zastosowania, Trybunał wielokrotnie odrzucał możliwość powołania się na dyrektywę przez osobę fizyczną przeciwko innej osobie fizycznej ${ }^{36}$.

Jednakże TS nie uznał tych argumentów rzecznika generalnego i odnosząc się do swojego rozstrzygnięcia w sprawie $M i l k o v a^{37}$, uznał, że w przypadku stwierdzenia dyskryminacji sprzecznej z prawem UE, dopóki nie zostaną przyjęte środki zmierzające do zapewnienia równego traktowania, osobom należącym do grupy dyskryminowanej należy przyznać takie same korzyści, jakie przysługują osobom uprzywilejowanym. Warunkiem jest jednak to, aby istniał odpowiedni system odniesienia, którym w sprawie w postępowaniu głównym jest bez wątpienia regulacja dotycząca członków Kościołów chrześcijańskich wskazanych w regulacji austriackiej. W rezultacie Trybunał w końcowej części rozstrzygnięcia Cresco Investigation doszedł do wniosku, że z art. 21 Karty wynikają zobowiązania nie tylko dla państwa członkowskiego w zakresie dokonania odpowiedniej zmiany sprzecznych z nim przepisów krajowych, ale

${ }_{33}$ Opinia z 25 lipca 2018 r., C-193/17, Cresco Investigation GmbH v Markus Achatzi, ECLI: EU:C:2018:614.

${ }^{34}$ Ibid.: pkt 126-127. W dalszej części opinii rzecznik Bobek przytoczyły także argumenty przemawiające za racjonalnością odmowy bezpośredniego skutku horyzontalnego przepisów Karty. Por. szerzej pkt 139-145 opinii.

35 Ibid.: pkt 183.

${ }^{36}$ Ibid.: pkt 192.

37 Wyrok TS z 9 marca 2017 r., C-406/15 Petya Milkova v Izpalnitelen direktor na Agentsiata za privatizatsia $i$ sledprivatizatsionen kontrol, ECLI:EU:C:2017:198: pkt 67. 
także dla prywatnych pracodawców podlegających tym regulacjom. Mianowicie, do czasu ich zmiany ci ostatni maja obowiązek przyznać również swoim pozostałym pracownikom (a zatem nienależącym do wskazanych przez ustawę Kościołów chrześcijańskich) prawo do dnia wolnego od pracy w Wielki Piątek, o ile pracownicy ci uprzednio wystapili o zwolnienie $\mathrm{z}$ obowiązku pracy $\mathrm{w}$ tym dniu, oraz prawo do dodatku do wynagrodzenia pobieranego za pracę świadczoną w tym dniu, jeśli nie uwzględniono takiej prośby. Tym samym TS uznał wprost bezpośredni skutek horyzontalny zawartej w art. 21 Karty zasady niedyskryminacji.

\section{PRZYCZYNY, ZAKRES I MOŻLIWE KONSEKWENCJE BEZPOŚREDNIEJ SKUTECZNOŚCI ZASADY NIEDYSKRYMINACJI}

Rozstrzygnięcie w sprawie Cresco Investigation można uznać za kontynuację wcześniejszej linii orzeczniczej Trybunału. Niemniej jednak zawiera ono w sobie bardzo ważny element, który sprawia, że możemy je określić mianem przełomowego dla zagadnień będących przedmiotem niniejszego artykułu. Mianowicie, wszystkie wcześniejsze sprawy, takie jak Mangold, Kücükdeveci, Dansk Industri, Egenberger czy IR v. JQ, dotyczyły tzw. bezpośredniego skutku wykluczajacego (ang. horizonatl exclusion effect), czyli sytuacji, gdy umowa między podmiotami prywatnymi opiera się na regulacji krajowej, która jednak po zbadaniu okazuje się sprzeczna z ogólną zasada niedyskryminacji. Wówczas $\mathrm{w}$ związku z obowiązkiem uwzględnienia postanowienia prawa pierwotnego UE wykluczona jest możliwość zastosowania sprzecznej z nim normy krajowej, także w relacji między jednostkami ${ }^{38}$. Dlatego też niektórzy przedstawiciele doktryny odnoszą się do tej sytuacji jako do przykładu stosowania zasady pierwszeństwa prawa unijnego w krajowych porządkach prawnych ${ }^{39}$. Jak wyżej wskazano, podobne stanowisko zajał rzecznik generalny Bobek w swojej opinii w sprawie Cresco Investigation. Wskazał bowiem, że „prawo do niedoznawania dyskryminacji” należy uznać za następstwo zasady pierwszeństwa prawa UE, a nie jego bezpośredniej skuteczności. Uznał także, że wyrok w sprawie Egenberger potwierdził jedynie pierwszeństwo unijnego prawa pierwotnego w postaci regulacji art. 21 ust. 1 Karty w kontekście sporu między podmiotami prywatnymi, sugerując zarazem, że TS nie powinien zajmować dalej idącego stanowiska ${ }^{40}$. Jak już jednak wskazano, Trybunał zdecydował się na kolejny krok i uznał tzw. bezpośredni skutek substytucyjny (ang. horizontal substitution effect) art. 21 ust. 1 Karty, co oznacza, że nie wystarczy uchylić sprzeczną z nim normę krajowa, ale do tego czasu trzeba zapewnić mu pełną skuteczność, także w relacjach horyzontalnych.

\footnotetext{
38 Sever (2014): 42.

39 Craig, de Búrca (2015): 184-224.

40 Opinia w sprawie C-193/17, EU:C:2018:614: pkt 140.
} 
Pojawia się zatem pytanie, dlaczego TS, który odmawia bezpośredniego skutku horyzontalnego dyrektywom (zostało to potwierdzone również w sprawie Cresco Investigation), tym razem nie zawahał się i przyznał taki skutek unijnej zasadzie niedyskryminacji. Odpowiedź wydaje się oczywista - Trybunał chce zapewnić ochronę ofiar dyskryminacji, natomiast drugorzędne znaczenie ma eliminacja sytuacji, w której podmioty dyskryminujące unikają odpowiedzialności z tego tytułu. W istocie w swoim orzecznictwie konsekwentnie podkreśla, że art. 21 ust. 1 Karty jest nie tylko źródłem ogólnej zasady niedyskryminacji, ale wynika z niego prawo podmiotowe do jej niedoznawania (do równego traktowania), na które można się powołać nie tylko przeciwko państwom członkowskim czy instytucjom unijnym, ale także przeciwko innym jednostkom w sporach mieszczacych się w zakresie zastosowania prawa UE. Należy zatem pozytywnie zweryfikować postawioną we wstępie hipotezę, z pewnym jednak uzupełnieniem. Warto bowiem zauważyć, że niektórzy przedstawiciele doktryny oraz rzecznicy generalni powołują się w tym względzie na art. 51 ust 1 Karty, z którego wynika, że zakres zastosowania tego aktu obejmuje jedynie państwa członkowskie i instytucje unijne, a nie podmioty prywatne ${ }^{41}$. Można jednak spotkać się również z takim poglądem, że bezpośredni skutek horyzontalny nie jest wyłączony na podstawie tego postanowienia w stosunku do jakiejkolwiek części Karty ${ }^{42}$. Podobne stanowisko zają TS w swoim orzecznictwie - w wyroku w sprawie Bauer ${ }^{43}$ odniósł się wprost do art. 51 ust. 1 Karty i uznał, że regulacja ta „nie odnosi się do kwestii, czy takie osoby [prywatne - J.M.-N.] moga, w stosownych przypadkach, być bezpośrednio związane niektórymi postanowieniami wspomnianej Karty, a zatem nie można go interpretować w ten sposób, że systematycznie wyklucza taka ewentualność".

W kontekście przyczyn uznania art. 21 ust. 1 Karty za bezpośrednio skuteczny również w układzie horyzontalnym duże znaczenie ma argument wskazywany przez sam Trybunał w jego orzecznictwie, wspomniany także w wyroku w sprawie Cresco Investigation. Mianowicie, podkreśla się, że art. 21 Karty nie różni się co do zasady od postanowień traktatowych zakazujących dyskryminacji opartej na różnych kryteriach, nawet jeśli jest ona następstwem umów zawartych między jednostkami. Logiczną konsekwencja posiadania przez Kartę tego samego statusu, jaką mają Traktaty (art. 6 ust. 1 TUE), jest przyznanie jej postanowieniom takiego samego skutku. Trudno byłoby zwłaszcza wyobrazić sobie, że niektóre z regulacji Karty, powtarzające bezpośrednio skuteczne horyzontalnie prawa traktatowe (np. prawa do równej płacy), byłyby pozbawione tej cechy ${ }^{44}$. Przyczyna przyznania zasadzie niedyskryminacji pełnej bezpośredniej skuteczności jest zatem chęć zapewnienia możliwie najszerszej ochrony ofiar dyskryminacji, niezależnie od tego, czy opiera się ona przepisach zawartych w Traktatach czy Karcie.

${ }^{41} \mathrm{~W}$ polskie literaturze por. np. Kułak (2019): 36.

${ }^{42}$ Tak m.in. Frantziou (2019): 317.

${ }^{43}$ Wyrok TS z 6 listopada 2018 r., sprawy połączone C-569/16 i C-570/16, Stadt Wuppertal $v$ Maria Elisabeth Bauer and Volker Willmeroth v Martina Broßonn, ECLI:EU:C:2018:871: pkt 87.

${ }^{44}$ Frantziou (2015): 660. 
Jeśli chodzi o zakres bezpośredniego skutku tytułowej zasady, to nie ma wątpliwości, że występuje on zarówno w układzie wertykalnym (pionowym), jak i horyzontalnym (poziomym). W rezultacie jednostka może powoływać się na nia, a tym samym domagać się równego traktowania z innymi osobami znajdującymi się w podobnej sytuacji, zarówno w stosunku do państw członkowskich czy instytucji unijnych, jak i innych podmiotów prywatnych. Należy też podkreślić, że TS w swoim orzecznictwie uznał występowanie nie tylko bezpośredniego skutku wykluczającego zasady niedyskryminacji, z którego wynika wymóg uchylenia sprzecznych z nią norm krajowych, ale również uwzględnił bezpośredni skutek substytucyjny, co oznacza, że należy zapewnić jej pełną skuteczność w praktyce. Pojawia się jednak pytanie, w jaki sposób to uczynić. Odpowiedzi udziela sam Trybunał w swoim orzecznictwie, wskazując na tzw. istotny punkt odniesienia. Oznacza to, że musi istnieć osoba (lub grupa osób, np. członkowie niektórych Kościołów), która korzysta z pewnych przywilejów (np. prawo do urlopu w Wielki Piątek lub wynagrodzenia za dzień ustawowo wolny od pracy). W rezultacie bezpośredniego zastosowania zasady niedyskryminacji takie same prawa powinny być przyznane osobom dyskryminowanym, jeśli zajdzie taka potrzeba również przez podmioty prywatne (np. pracodawców). Warto jednak zauważyć, że możliwość ta pojawia się tylko wówczas, jeśli przepisy krajowe nie moga zostać zinterpretowane w sposób zgodny z dyrektywą 2000/78/WE. Trybunał Sprawiedliwości podkreśla tym samym, że bezpośredni skutek horyzontalny art. 21 ust. 1 Karty nie jest automatyczny, ale należy się do niego odwołać w ostateczności, jeśli postanowienia tej dyrektywy nie mogą wywołać pośrednich skutków (poprzez prounijną wykładnię regulacji krajowych).

Warto także rozważyć, jakie mogą być skutki przyjętej w orzecznictwie koncepcji, że tytułowa zasada wywołuje zarówno bezpośrednie skutki wertykalne, jak i horyzontalne. W tym zakresie można pozytywnie zweryfikować druga z hipotez przyjętych we wstępie, że skutkiem takiego podejścia Trybunału jest nałożenie na podmioty prywatne dodatkowych zobowiązań w zakresie przestrzegania unijnej zasady niedyskryminacji, także wówczas (a może zwłaszcza), gdy krajowe regulacje prawne są z nią sprzeczne. Oczywiście można by rozważać, jak to uczynił rzecznik generalny Bobek w swojej opinii, dlaczego pracodawcy mają ponosić koszty stosowania nieprawidłowego ustawodawstwa krajowego. Być może takie pytanie byłoby zasadne w innej sprawie, jednakże tutaj mamy do czynienia z przestrzeganiem jednej z podstawowej zasad, jaka jest zasada niedyskryminacji i pracodawcy również nie powinni czerpać korzyści z jej naruszania, a tak działo się w stanie faktycznym w sprawie Cresco Investigation. W takich zaśs sytuacjach wywoływanie przez przepis art. $21 \mathrm{KPP}$ bezpośrednich skutków, także w układzie horyzontalnym, nie powinno być kwestionowane ${ }^{45}$.

Ponadto - jak podkreśla się w doktrynie - mamy obecnie do czynienia z zacieraniem się wyraźnego podziału na sferę publiczną i prywatną oraz wzrostem znaczenia fundamentalnych praw człowieka jako zasad ogólnych, stąd

${ }^{45}$ Maliszewska-Nienartowicz (2020): 17. 
też brak ochrony jednostek przed naruszaniem niektórych zasad przez inne podmioty prywatne może zagrozić ogólnej skuteczności systemu ochrony praw ustanowionego przez $\mathrm{UE}^{46}$. Nie ma jednak wątpliwości, że wraz z uznaniem bezpośredniego skutku horyzontalnego zasady niedyskryminacji Trybunał przenosi na osoby fizyczne i prawne (np. pracodawców) część ciężaru związanego z ochroną praw podstawowych, które jak dotąd spoczywały na państwach członkowskich - w przypadku naruszenia praw wynikających z prawa UE podmioty sa zobowiazzane do ich przyznania ${ }^{47}$. W związku z tym podmioty prywatne powinny być świadome faktu, że sa związane nie tylko przepisami krajowymi, ale mają również dodatkowe obowiązki, w szczególności związane z przestrzeganiem ogólnych zasad prawa UE.

\section{UWAGI KOŃCOWE}

Z orzecznictwa Trybunału wynika, że art. 21 ust. 1 Karty może być powoływany w sytuacji, gdy normy dyrektywy 2000/78/WE nie wywołują bezpośredniego skutku, a jednocześnie postanowień prawa krajowego nie da się zinterpretować w ich świetle. Możliwość ta pojawia się przy tym nie tylko w układzie państwo członkowskie czy instytucja unijna - jednostka, ale również w sporach między podmiotami prywatnymi. Trybunał uznał przy tym bezpośredni skutek substytucyjny art. 21 ust. 1 Karty, co oznacza, że należy zapewnić jej pełną skuteczność w praktyce, a zatem poza niestosowaniem (a w konsekwencji uchyleniem) sprzecznej z nim normy krajowej trzeba przyznać osobom dyskryminowanym takie same prawa, jak te, z których korzystają osoby w jakikolwiek sposób uprzywilejowane. To ostatnie zobowiązanie spoczywa nie tylko na państwach członkowskich czy instytucjach unijnych, ale w odpowiednich przypadkach również na jednostkach. W rezultacie w sytuacji, gdy przywoływana jest unijna zasada niedyskryminacji, nie będą one korzystały z naruszenia, jakiego dopuściło się państwo członkowskie, jak to jest w przypadku powoływania się na normy dyrektyw ${ }^{48}$.

Oczywiście nie oznacza to, że Trybunał dokonuje zmiany w zakresie swojego orzecznictwa dotyczącego bezpośredniego skutku tych ostatnich. W wyroku w sprawie Cresco Investigation wyraźnie podkreślił, że „nie można powoływać na dyrektywę w sporze między jednostkami w celu wyłączenia stosowania uregulowania państwa członkowskiego sprzecznego z tą dyrektywa" ${ }^{\prime 9}$. W dalszej części tego rozstrzygnięcia wskazał jednak, że w tym przypadku chodzi o regulację art. 21 ust. 1 Karty, a ta ma walor prawa pierwotnego. Powinna zatem wywoływać takie same skutki prawne, jak traktaty. Przy tak logicznym uzasadnieniu bezpośredniego skutku tej normy i zawartej w nim zasady niedyskryminacji nie wydaje się, aby orzecznictwo TS mogło w przyszłości ulec zmianie na nieko-

\footnotetext{
46 Fontanelli (2011): 233.

47 Fontanelli (2011): 238-239.

48 Fontanelli (2011): 238.

49 Wyrok w sprawie C-193/17: pkt 73.
} 
rzyść jednostek. Jeśli zaś ta linia orzecznicza zostanie utrzymana w kolejnych rozstrzygnięciach, to będzie miała ona niebagatelne znaczenie dla zwiększenia zakresu ochrony przed nieuzasadnionym nierównym traktowaniem opartym na różnych kryteriach wskazanych w art. 21 ust. 1 Karty.

Ciacchi, A.C. (2019). The direct horizontal effect of EU Fundamental Rights. ECJ 17 April 2018, Case C-414/16, Vera Egenberger v Evangelisches Werk für Diakonie und Entwicklung e.V. and ECJ 11 September 2018, Case C-68/17, IR v JQ. European Constitutional Law Review 15(2): 294-305.

Craig, P., De Búrca, G. (2015). EU Law: Text, Cases and Materials. Oxford University Press.

De Mol, M. (2011). The novel approach of the CJEU on the horizontal direct effect of the EU principle of non-discrimination: (unbridled) expansionism of EU law? Maastricht Journal of European and Comparative Law 18(1/2): 109-135.

Fontanelli, F. (2011). Some reflections on the general principles of EU and on solidarity in the aftermath of Mangold and Kücükdeveci. European Public Law 17(2): 225-240.

Frantziou, E. (2015). The horizontal effect of the Charter of Fundamental Rights of the European Union: rediscovering the reasons for horizontality. European Law Journal 21(5): 657-679.

Frantziou, E. (2019). (Most of) the Charter of Fundamental Rights is horizontally applicable: ECJ 6 November 2018, joined cases C-569/16 and C-570/16, Bauer et al. European Constitutional Law Review 15(2): 306-323.

Kułak, M. (2019). Skutek bezpośredni zasady niedyskryminacji w relacjach horyzontalnych - glosa do wyroku Trybunału Sprawiedliwości z 22.01.2019 r., C-193/17, Cresco Investigation. Europejski Przegląd Sądowy 6: 33-37.

Leczykiewcz, D. (2015). Effectiveness of EU law before national courts: direct effect, effective judicial protection and state liability, [w:] D. Chalmers, A. Arnull (eds.), The Oxford Handbook of European Union Law. Oxford University Press: 212-248.

Maliszewska-Nienartowicz, J. (2020). Pojęcie i źródła europejskiego prawa antydyskryminacyjnego, [w:] A. Wróbel, J. Maliszewska-Nienartowicz (red.), System prawa UE. Tom 6: Prawo antydyskryminacyjne. Warszawa: $1-37$.

Mik, C. (2000). Europejskie prawo wspólnotowe. Zagadnienia teorii i praktyki. Warszawa.

Schiek, D. (2010). Constitutional principles and horizontal effect: Kücükdeveci revisited. European Labour Law Journal 1(3): 368-379.

Wyatt, D. (2008). Horizontal effect of fundamental freedoms and the right to equality after Viking and Mangold, and the implications for Community Competence. Croatian Yearbook of European Law and Policy 4: 1-49.

Zaccaroni, G. (2010). Is the horizontal application of general principles ultra vires? Dialogue and conflict between supreme European courts in Dansk Industri. federalismi.it 9: 1-17.

\title{
THE DIRECT EFFECT OF THE GENERAL EU NON-DISCRIMINATION PRINCIPLE IN DISPUTES CONCERNING AREAS COVERED BY EUROPEAN UNION LAW
}

\author{
Sum mary
}

The article concentrates on a fundamental issue related to the effect of the EU non-discrimination principle. The preliminary research assumption was that the main purpose of extending the scope of its effectiveness, which can be observed in the jurisprudence of the Court of Justice, is primarily the wish to protect victims of discrimination, and only then to eliminate the situation in which discriminating entities avoid responsibility in this respect. It is also worth considering the consequences of the concept adopted in the case-law, namely that the EU non-discrimination principle has both vertical and horizontal direct effects. As a result, the first part of the article presents the development of the jurisprudence concerning the direct effect of the non-discrimination principle. Then the groundbreaking ruling in the case of Cresco Investigation GmbH (C-193/17) is discussed 
in detail. Finally, the analysis covers the reasons, scope and possible effects of the approach according to which the EU non-discrimination principle can be invoked directly in national courts also in the context of disputes between private parties. The final conclusions indicate possible further development trends in terms of the direct effect of the EU non-discrimination principle.

Keywords: EU non-discrimination principle; vertical and horizontal direct effect; scope of application of the EU non-discrimination principle; EU Charter of Fundamental Rights 
